\title{
LOW COST ANGLE CALCULATOR
}

\section{MICHAL TAKÁTS}

Vehicle Center of Sustainable Mobility, VTP Roztoky, Přilepská 192025263 Roztoky

michal.takats@fs.cvut.cz

\section{SHRNUTí}

Článek popisuje nově zavedený programový produkt určený ke zvýšení schopnosti laboratoře spalovacích motorů pro pořizování úhlově indexovaných záznamů rychle proměnlivých fyzikálních veličin. Předmětem zájmu je programové vybavení pro dodatečné převzorkování datových struktur zaznamenaných s využitím vnitřních hodin akvizičního modulu jako zdroje vzorkovacích impulzů. Výstupní datová struktura má stejný formát jako prímý záznam pořizený prii vzorkování impulzy z rotačního enkodéru, namontovaného na volný konec klikového hrídele motoru. V článku se vysvětluje motivace $k$ tvorbě předmětného SW produktu. Popisují se principy funkce. Uvádějí se příklady požití při výzkumných aktivitách pracoviště.

\section{KLICČOVÁ SLOVA: RYCHLYY SBĔR DAT, PŘEVZORKOVÁNÍ, ÚHLOVĔ INDEXOVANÁ DATA}

\section{ABSTRACT}

The article deals with a newly created SW tool dedicated to improving the ability of an engine test laboratory to acquire angle resolved records of fast changing quantities. In particular it deals with SW equipment dedicated to the off-line resampling of the data structures obtained using the acquisition module internal clock. The SW generates a format of data which is equivalent to that acquired using an external source of sampling and triggering pulse coupled to an engine crankshaft. The motivation for creation of this SW is explained and the principle of operation is described. An illustrative example of results is presented.

KEYWORDS: HIGH SPEED DATA ACQUISITION, RESAMPLING, ANGLE RESOLVED DATA

\section{INTRODUCTION}

Angle resolved records of (various) fast changing quantities are often an important part of experimentally acquired data during combustion engine oriented R\&D activities. The incylinder pressure record is a typical example. Its subsequent evaluation provides a wide range of useful data concerning the thermodynamics of an engine working cycle. The evaluation of results is also very useful for description of the mechanical and thermal strain experienced by the main engine components. Exact determination of mechanical losses is an additional valuable result. An angle resolved record of manifold pressures enables detailed investigation of turbocharger behavior under real on-engine conditions. It is clearly beneficial to attempt to utilize this experimental tool as often as possible.

The angle resolved records are sensed in a conventional way using a rotary encoder as a source of sampling events. The rotational part of the encoder is coupled directly to the crankshaft. Such sampling approach offers exact alignment of the scopes of the recorded physical quantity with the cranktrain position.
Various designs of rotational encoders are available on the market. Shaft driven optical encoders are considered the basic and the cheapest solution. Magnetic encoders with noncontact / frictionless transfer make for easy installation and display a high robustness appropriate for a harsh environment. Flange mounted encoders with transfer of raw signal via optical cables represents the absolute peak solution with respect to mechanical robustness and resistance to electromagnetic disturbances. Of course they are also the most expensive.

The use of a rotational encoder as a source of external sampling and triggering ticks is a well proven practice. Nevertheless, there are cases when the installation of the rotational encoder on a crankshaft free end is too complicated or even completely impossible.

It is sometimes problematic to ensure a sufficiently accurate alignment of the rotational part of the encoder with the crankshaft itself. Typically, installation of the stator part of the encoder coaxially with the crankshaft end is even more complicated. Additional complications occur when 
a torsional damper is installed at the crankshaft front end. All these problems are accentuated if acquisition of fast changing quantities is performed on the engine mounted in, for example, a vehicle. Since pressure transducers integrated into spark plug or glow plug adaptors have come onto the market, the installation of the rotational encoder is the most demanding part of preparation of the test specimen for incylinder pressure acquisition.

Even if the encoder is correctly installed, certain problems can occur during its exploitation. Electromagnetic incompatibility can affect the electrical transfer of sampling pulses. Frequently occurring false pulses destroy the acquired record completely. Even more harmful is the rare occurrence of false pulses, which act as undesirable sample events. At a typical angle resolution (e.g. $0.25^{\circ} \mathrm{CA}$ ) the occurrence of a few additional samples within the whole record may not be identified; nevertheless, both IMEP values and Heat Release curve are subsequently evaluated erroneously. Torsional flexibility of the coupling between the crankshaft end and the encoder input shaft may cause a phase shift. This is difficult to recognize due to its periodical character with the main harmonic components at identical frequencies to those included in the correct signal. The results of the thermodynamic evaluation are systematically biased. An analysis of this phenomenon is introduced in [1].

There is sufficient motivation to search for an alternative strategy for acquisition of the angle resolved records. Both the leading international suppliers of indication equipment (Kistler and AVL) offer a specific HW and SW accessory called an "angle calculator". Simultaneously with a time-based record of a monitored physical variable these devices also sense marks regularly distributed along the perimeter of an appropriate wheel rotating synchronously with the engine crankshaft. The flywheel gear teeth or the injection / ignition trigger wheel are appropriate carriers of the crankshaft phase information. The records of the monitored physical quantities and the signal from the phase sensor - all of them sampled by internal clock ticks - are evaluated in common. Finally, an angle resolved record is generated. The test bench output data are formatted in the same manner as if they had been sampled by the rotational encoder.

\section{IN-HOUSE AN GLE ENCODER}

\subsection{MOTIVATION}

As mentioned above, professional angle calculators are available. They offer full functionality of both on-line and offline evaluation of the acquired data similarly to the externally sampled and triggered records. These beneficial features are achieved thanks to the implementation of a sophisticated HW and SW arrangement. The signal from angle mark sensor is sampled at a significantly higher resolution. The resampling procedure is performed on-line using a custom designed processor-based HW device. This is what makes professional angle calculators expensive items of indication equipment. Moreover, both the above-mentioned suppliers offer their angle calculator only as a part of a complete indicating system (AVL - IndiModul, Kistler KiBox). It therefore seems reasonable to seek a cheaper solution so that this powerful tool can be used in the everyday experimental activity of several parallel testing facilities.

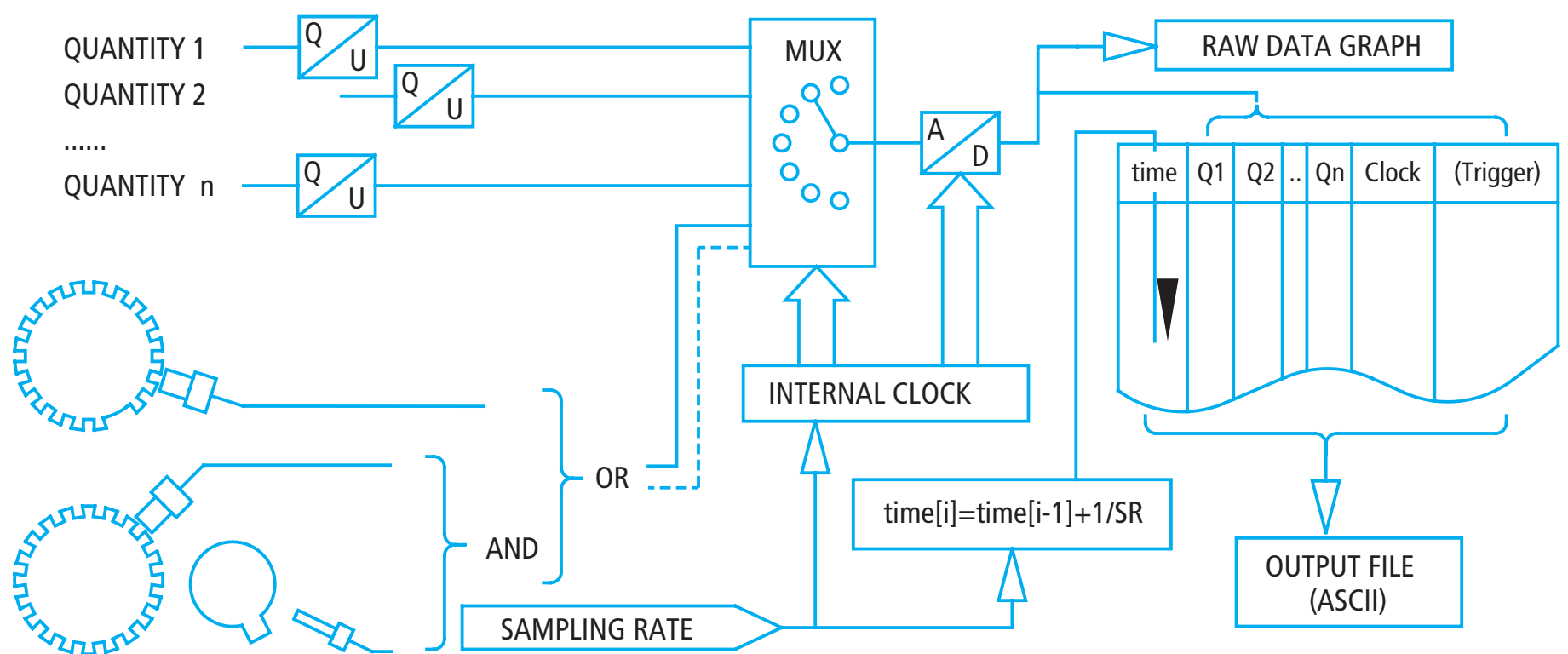

FIGURE 1: On-line HW \& SW Schematics

OBRÁZEK 1: Funkční schéma akvizičního programového vybavení 


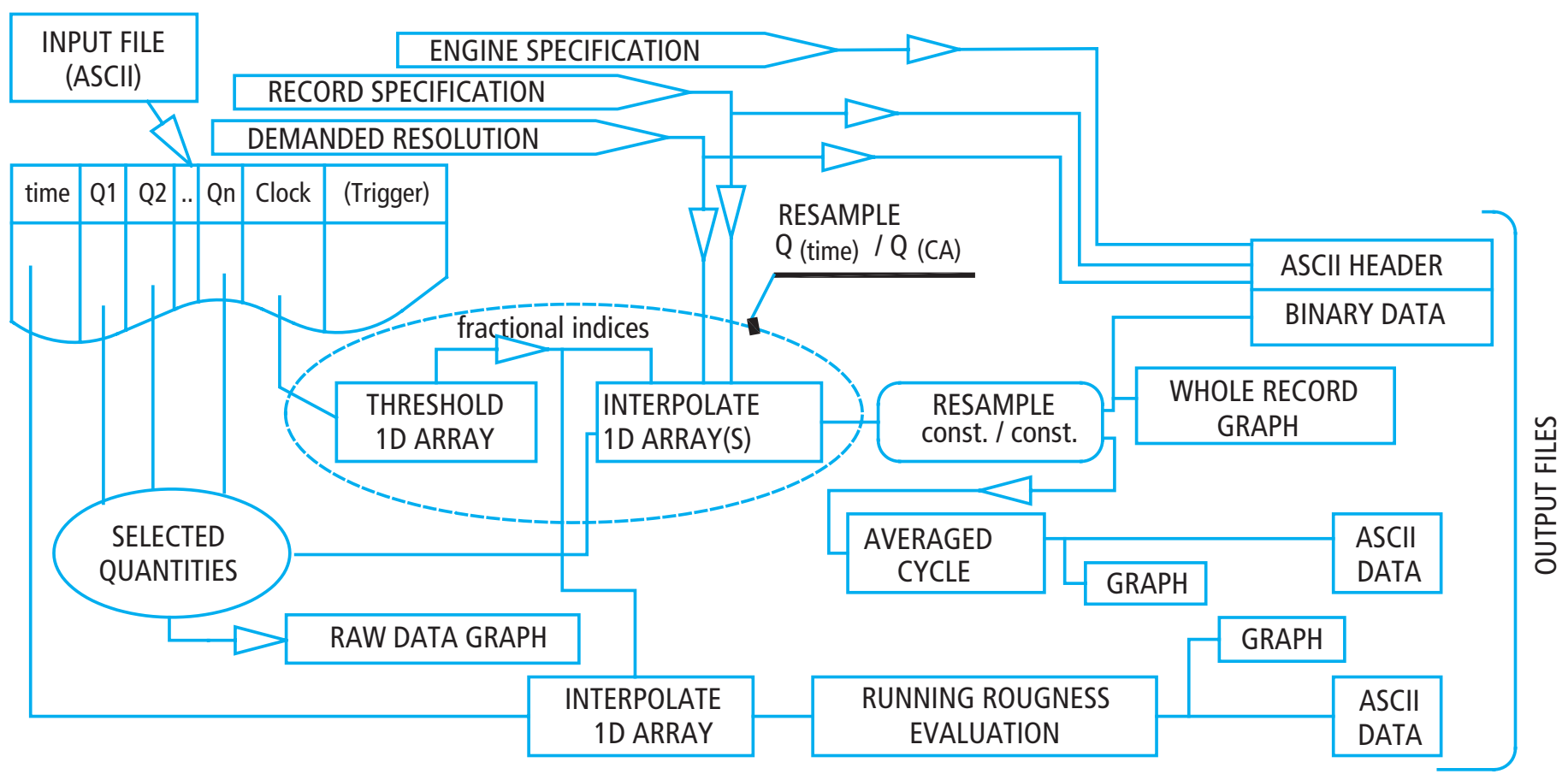

FIGURE 2: Off-line SW schematics

OBRÁzEK 2: Funkční schéma vyhodnocovacího SW

\subsection{PRINCIPLE OF OPERATION}

In order to simplify the HW equipment demands, certain functionality of the system has to be given up. The presented case moves away from the on-line real time functionality. Only raw data are displayed in the graph during experimental operation to enable direct visual judgment of the plausibility of the acquired signals. All subsequent evaluations are performed off-line.

The on-line arrangement of HW and SW components is introduced in Figure 1. The analog signal(s) from the sensor(s) facing the angle spaced marks is (are) integrated into the set of acquired channels. They are sampled with same sampling rate as other channels. The nature of the signal does not matter. The system works correctly with rectangular signals (optical or Hall sensor) as well as with sinusoidal patterns (possibly generated by a magnetic pick-up). The only restriction concerns the amplitude of the signal, which has to be maintained within the acceptable voltage range of the A/D converter module. The signal from the sensor facing the evenly spaced marks ("Clock") and possibly from the sensor generating one event a revolution ("Trigger") are appended at the end of the acquired channel list (the rightmost columns in Figure 1 - this arrangement is not essential; the phasing marks can be included in any column). The acquired data are completed by a vector of evenly spaced time data. Finally, an output file is saved.

The main part of the off-line evaluation is a procedure for resampling the time-resolved data into the angle-resolved

format. It basically consists of two steps. In Figure 2 the first operation is called "THRESHOLD 1D ARRAY". It uses the "Clock" data as an input. It seeks the occurrence of the real regularly angle distributed events i.e. the intersections of the acquired sensor voltage curve with a pre-adjusted threshold. This operation finds a pair of consecutive elements of the "Clock" vector such that the threshold is greater than the value of the first element and less than or equal to the value of the second element. The noninteger part of the "fractional index" is determined by a linear interpolation between these two elements.

It is assumed that the rotational speed is constant between two consecutive "Clock" events. An evenly spaced subarray of the fractional indices is generated which divides the interval between the two consecutive "Clock" events into an integer number of the regularly spaced angle intervals. For these fractional indices the values of all relevant quantities are calculated using the "INTERPOLATE 1D ARRAY" routine. The mentioned routines are repeated in a loop until the whole length of the acquired data is elaborated. The sequences (subarrays) of values of each physical quantity are appended, creating a vector of the angle-resolved data.

The mentioned procedure generates a number of the samples per revolution which is an integer multiple of the number of the physical marks along the perimeter of the mark wheel. This fact does not restrict further usability of the data in any way; however, 
somewhat "exotic" angle intervals are generated for a certain number of the physical marks. This may be considered awkward for further processing. If this feature is considered undesirable the data can be resampled in a constant-to-constant manner.

The whole SW (both on-line and off-line) was compiled using the LabVIEW ${ }^{\top M}$ development environment. In-built routines "Interpolate 1D Array" and "Resample Waveforms" are used in the corresponding topics in Figure 2. The "THRESHOLD 1D ARRAY" procedure was composed by the author because the LabVIEW ${ }^{T M}$ in-built equivalent ("Threshold 1D Array") operates only on a non-descending sequence of data i.e. it finds only the first occurrence of the threshold intersection.

The described procedures ensure the correct angle-resolved spacing of the output data structures. There is an additional demand for correct phasing of whole record i.e. for maintaining the same TDC position in all acquired records at various engine operating points. If the rotational encoder is used, the trigger channel generating one event per revolution takes responsibility for this task.

If the described angle calculator is implemented, the task is easily performed in the case depicted in the bottom left part of Figure 1. In this case the off-line SW simultaneously loads the data from the disk file and scans the "Trigger" column for the first occurrence of the trigger event (i.e. the first intersection of the voltage signal with a pre-adjusted level). After the data are loaded completely they are trimmed at the beginning by skipping the pre-trigger part.

The in-house angle calculator (as with the professional versions) is able to operate using a trigger wheel with one extra sample event (skipped mark) per revolution as indicated in the upper

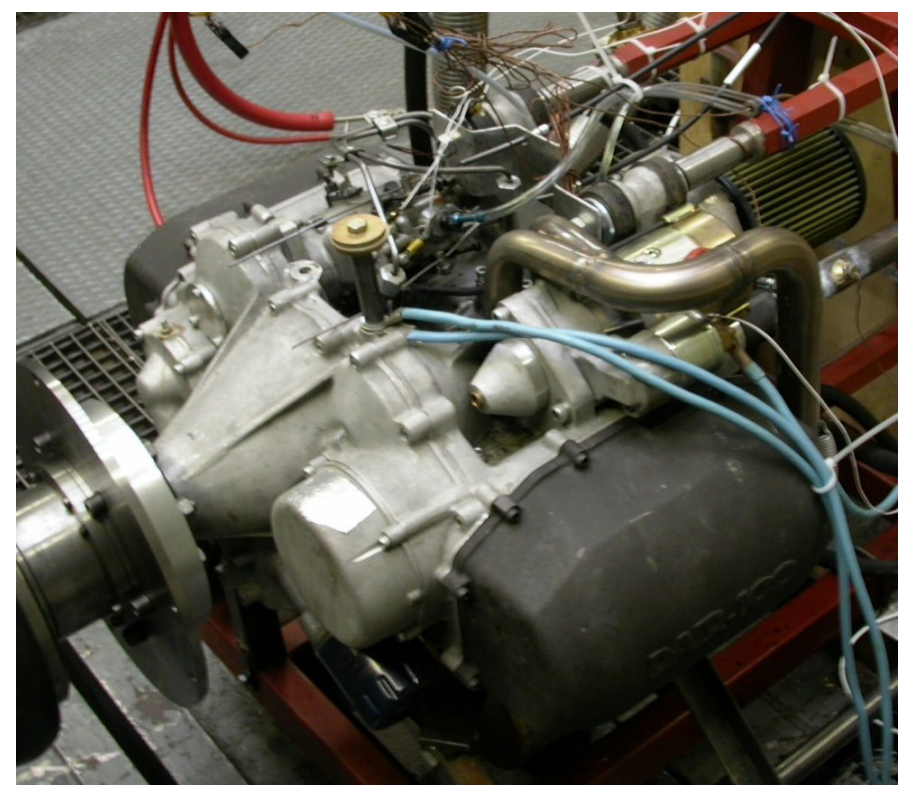

FIGURE 3: DAPL A (Diesel Air) Engine

OBRÁZEK 3: Funkční vzorek „A" motoru DAPL alternative in Figure 1. In this case the in-house resampling procedure also seeks the occurrence of an unusually long gap between consecutive events. The resampling itself starts after this trigger event occurs. Moreover, the number of output samples between the consecutive events in the "Clock" channel is recalculated correspondingly (typically doubled for one skipped mark). In addition the counts of the regular marks between the consecutive trigger events are checked along the whole record to enhance the plausibility of the phase alignment.

Further elaboration of data depends on how they will subsequently be used. In the current state the data can be formatted as an equivalent of the high speed acquisition output, as performed in the author's laboratory (sampled by the external clock / trigger pulse from the rotational encoder). Full functionality of each branch of the subsequent sophisticated evaluation is preserved in this way.

As a common output, averaged data are created which contain for each angle position the value of the relevant physical quantity averaged for the given position along the whole sequence of the consecutive cycles. The data file can be stored on disc as an ASCII table.

The off-line SW offers several additional functionalities.

Once the "THRESHOLD 1D ARRAY" procedure is established it can be applied to the first column of the original record. From the difference between the consecutive elements of the resampled time vector (i.e. the instantaneous period of the periodical event occurrence) the instantaneous crankshaft speed can be calculated. In this way the periodical (and even non-periodical) running roughness can be evaluated. The evaluation procedure also involves determination of an angle
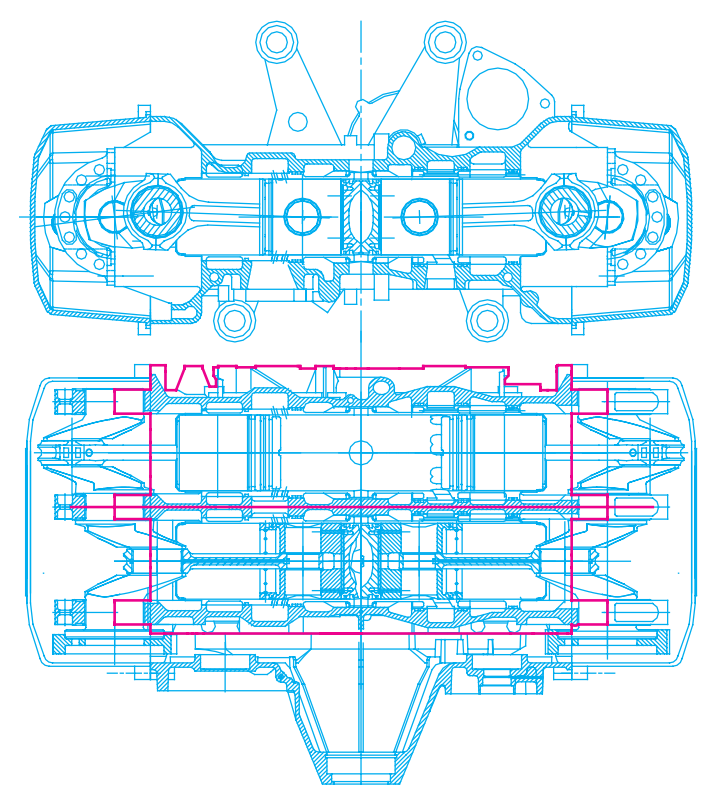
shift between the crankshaft and a fictive body rotating with constant rotational speed. Very effective implementation of Fast Fourier Transform as a LabVIEW ${ }^{\mathrm{TM}}$ in-built function enables the smoothing and averaging of the instantaneous speed curve using an inverse composition of the final shape from the significant main harmonic components only. The same feature is exploited for determination of the instantaneous angular acceleration using an analytic derivation of FFT output followed by the implementation of IFT.

In particular, when the in-cylinder pressure record is the subject of interest, the off-line SW offer calculations of cranktrain kinematics enabling the visualization of the $p-v$ diagram and calculation of the IMEP value(s) for the relevant cylinder(s). Even calculation of the instantaneous torque can be performed using the in-cylinder (and possibly crankcase if available) pressure traces(s) which can be compared with the results of running roughness evaluation.

\subsection{EXAMPLE OF RESULTS}

The functionality of the angle calculator will be demonstrated using the data structure acquired during the development of a two stroke - cycle diesel engine with opposed pistons. The specific design of the first specimen of the Diesel Air Power Lite engine is introduced in Figure 3. It is clear from the drawing in the right-hand part of this figure that the crankshaft is completely inaccessible. The second specimen (Figure 4) shows slightly more favorable conditions. The crankshaft free end is accessible; however, there are still no options for attaching the stator part of the rotational encoder.

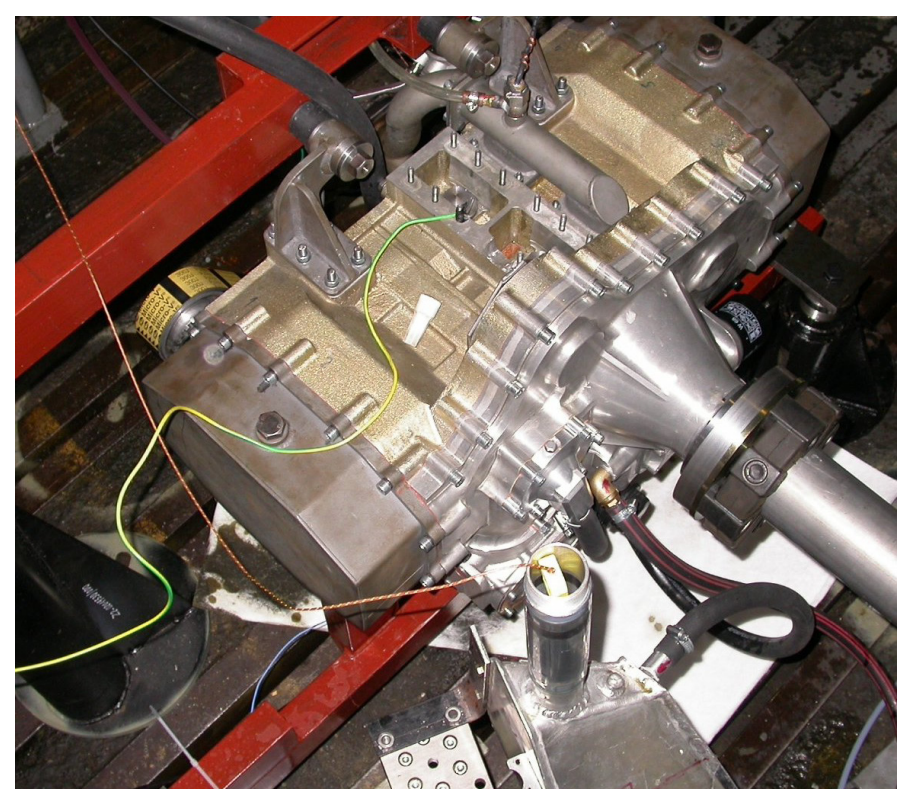

FIGURE 4: DAPL B Engine

OBRÁZEK 4: Funkční vzorek „B“ motoru DAPL
In the right-hand photograph in Figure 4 the trigger ring for the Common Rail injection system is visible behind the pulley at the rear end of crankshaft (dedicated for driving a volumetric compressor). The trigger ring has what is termed as a 36-1 design, i.e. it has 35 teeth with a spacing of $10^{\circ} \mathrm{CA}$.

A National Instrument PCI 6229 card was used for data acquisition. It offers a maximum sampling rate of $250 \mathrm{kS} / \mathrm{s}$. In the mentioned case the pressures in both cylinders, in the intake space and in the exhaust manifold were acquired. The fifth channel was used for acquisition of a signal from a Hall sensor facing the teeth on the trigger ring. Maximum sample rate per channel is then $50 \mathrm{kS} / \mathrm{s}$.

Somewhat unusual patterns are displayed as an illustration of the functionality of the angle calculator. The acquisition was performed with no pressure sensors connected to the multiplexer input during the tuning of the procedures described in this article. From Figure 5 the impact of the well-known data acquisition error of frequency leakage is clearly visible.

Frequency leakage causes the appearance of a signal which is similar to the previous channel (in order of the consecutive sampling). In this case the previous channel contains a rectangular signal from the Hall sensor. Each edge on the Hall sensor signal is deformed into the branch of an exponential curve approaching asymptotically the rated voltage levels. The relationship to the physical sampling pulse is easy to recognize. Curves in Figure 5 were acquired at a crankshaft speed of $2200 \mathrm{rpm}$.

In the upper part of Figure 5 the segment of the time based (=original) curve in the vicinity of the skipped tooth is displayed. The horizontal axis is described in seconds. The bottom part

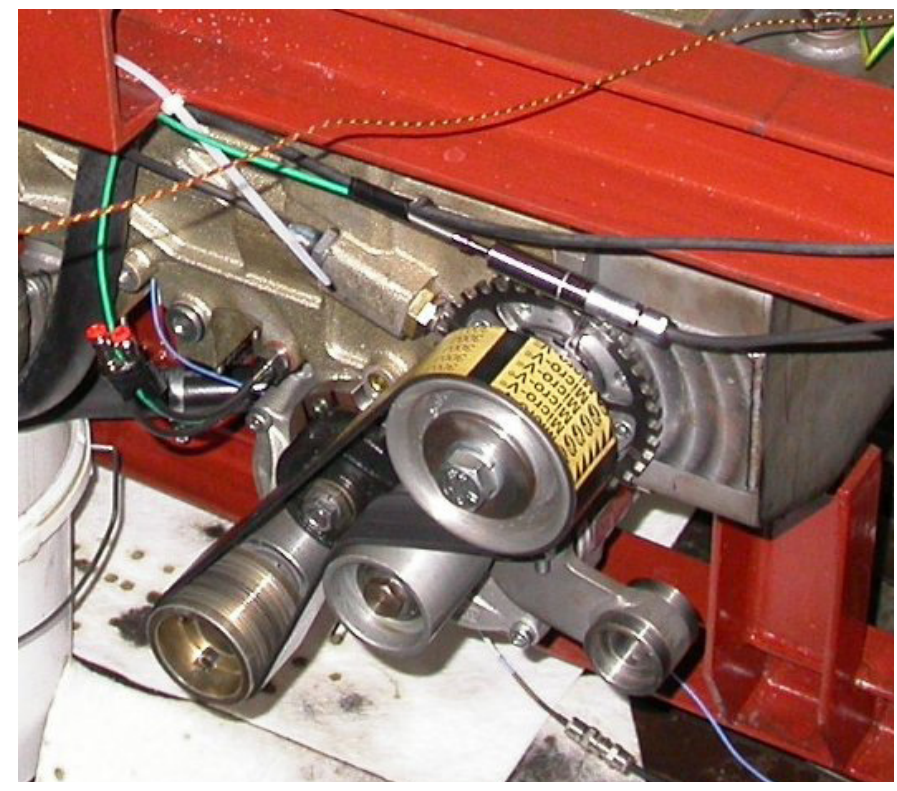

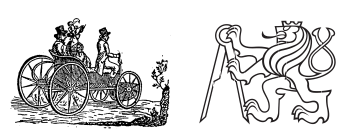


shows approximately the same segment of the data, this time with the points distributed regularly at an interval of $0.5^{\circ} \mathrm{CA}$. It is clearly apparent that there is no significant loss of the information contained in the original signal.

\section{CONCLUSION}

The angle resolved record of the fast changing quantities is a powerful experimental tool enabling a deep insight into the behavior of the engine working substance during the engine working cycle. At the same time the corresponding equipment is one of the most expensive parts of the data acquisition system. The presented proposal of a cost effective angle calculator should contribute to a more widespread application of this tool whilst keeping both the expense and the restriction of the functionality to an acceptable level.

The achieved functionality can be evaluated as follows:

At the sampling rate of $50 \mathrm{kS} / \mathrm{s}$ per channel (as in the above described example) the average angle resolution of $0.5^{\circ} \mathrm{CA}$ would be reached at an engine speed of $4200 \mathrm{rpm}$. Altogether 5 channels can be acquired using this sampling frequency. A maximum of 2 of them are occupied by the angle calculator itself. Therefore the typical high speed acquisition task (e.g. acquisition of the data for the Three Pressure Analysis) can be performed with sufficient capacity.

The acquisition module which was used for the implementation of the mentioned proposal is the cheaper version of the module which is commonly used in the author's laboratory for the sensing and recording of the slowly changing values as a main part of a basic data acquisition system for each test bench. The required additional expenses are reasonably low.

\section{REFERENCE}

[1] Vávra, J. (2002). Netradiční využití analýzy otáčení klikového hř́dele. In: Zborník z medzinárodnej vedeckej konferencie. Nitra : Slovenská Pol'nohospodárska univerzita v Nitre, 2002, díl 1, s. 53-58. ISBN 80-8069-051-0.

\section{ACKNOWLED GEMENTS}

The experimental method described in the article was developed using the support of EU Regional Development Fund in OP R\&D for Innovations (OP VaVpl) and Ministry for Education, Czech Republic, project \# CZ.1.05/2.1.00/03.0125 Acquisition of Technology for Vehicle Center of Sustainable Mobility.

The demonstration data were obtained in the framework of research project FR-TI1/580 "Research and Development of Two Stroke Diesel Engine with Contra-rotating pistons" supported by Ministry of Industry and Trade of the Czech Republic.

This support is gratefully acknowledged. 